IRA-International Journal of Education \& Multidisciplinary Studies

ISSN 2455-2526; Vol.04, Issue 02 (2016)

Pg. no. 271-277

Institute of Research Advances

http://research-advances.org/index.php/IJEMS

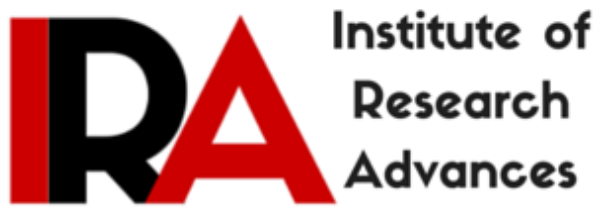

\title{
Depression: Psycho-Yogic way to over-come depression
}

\section{Dr. Vaishali Gaur}

Assistant Professor, Psychology,

University of Patanjali, Haridwar, India.

Type of Review: Peer Reviewed

DOI: http://dx.doi.org/10.21013/jems.v4.n2.p5

\section{How to cite this paper:}

Gaur, V. (2016). Depression: Psycho-Yogic way to over-come depression. IRA

International Journal of Education and Multidisciplinary Studies (ISSN 2455-2526), 4(2), 271-277. doi:http://dx.doi.org/10.21013/jems.v4.n2.p5

(C) Institute of Research Advances

\section{(cc) EY-NC}

This work is licensed under a Creative Commons Attribution-Non Commercial 4.0 International License subject to proper citation to the publication source of the work.

Disclaimer: The scholarly papers as reviewed and published by the Institute of Research Advances (IRA) are the views and opinions of their respective authors and are not the views or opinions of the IRA. The IRA disclaims of any harm or loss caused due to the published content to any party. 


\begin{abstract}
Today most of the person are suffering from various mental health troubles and looking for hope at yogic techniques. Due to bad thoughts and negative feelings the mood and emotional state of a person swing and become distorted. If such state remains for a long time, then a person may suffer from mood disorder or can becomes depressive. Mood disorder refers to one of a group of disorders primarily affecting emotional tone. Nowadays there is an increasing interest to use Yoga for health benefits and treating disease. The aim of the present research paper was to evaluate the use of Yoga in managing depression with proposed mechanism of the yogic technique duly supported by researchers.
\end{abstract}

Keywords: depression, yoga, Psychology, mental wellness

Life is full of challenges so each person feels down and ups in life. To lead a healthy and balanced life each person tries to establish good interpersonal relationship with each other's. As we know that human behaviour is the outcome of interaction among stimulus, organism and environment. If disturbance is created among the interaction of stimulus, organism and environment, the behaviour of a person becomes maladjusted. Thought and feelings also play a very prominent role in human life. Due to bad thoughts and negative feelings the mood and emotional state of a person swing and become distorted. If such state remains for a long time, then a person may suffer from mood disorder or can becomes depressive. Mood disorder refers to one of a group of disorders primarily affecting emotional tone.

Depression is a serious mental disorder. Now a day, most of the persons are suffering from this disorder. It is a state of low mood and aversion to activity that can affect a person's thoughts, behaviour, feelings and sense of well-being. This disorder may be developed in any age of life and both gender is affected by this disorder. Depression is very common. Really, $21.3 \%$ women and $12.7 \%$ males feel depression. (Kessler, 1994). On the basis of above description, it is said that gender differences are found in this disorder. Women are more affected than men by this disorder.

Across many nations, cultures, and ethnicities, women are about twice as likely as men to develop depression. (Nolen-Hoeksema, 2001)

\title{
Nature of Depression
}

Depression is a prime cause of mental illness. Depression refers to generating sadness in mood. It is a clinical syndrome consisting of five symptoms like: cognitive, emotional, motivational, behavioral and somatic. The description of five symptoms are given below in the table no 1 .

\begin{tabular}{|c|c|c|}
\hline S.no & Type & Symptoms \\
\hline 1. & Cognitive & $\begin{array}{ll}\text { - } & \text { Negative thinking } \\
\text { - } & \text { Lack of self-esteem } \\
\text { - } & \text { Feeling of uselessness } \\
\text { - } & \text { Feeling of inadequacy } \\
\text { - } & \text { Ideas of death and suicide }\end{array}$ \\
\hline 2. & Emotional & $\begin{array}{ll}\text { - } & \text { Sadness } \\
\text { - } & \text { Disappointment } \\
\text { - } & \text { Shyness } \\
\text { - } & \text { Guilt feeling } \\
\text { - } & \text { Unhappiness, }\end{array}$ \\
\hline
\end{tabular}




\begin{tabular}{|c|c|c|}
\hline 3. & Motivational & 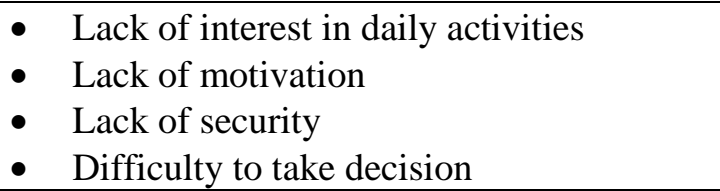 \\
\hline 4. & Behavioral & $\begin{array}{ll} & \text { Lack of productivity } \\
\text { - } & \text { Laziness } \\
\text { - } & \text { Decreased psychomotor activity } \\
\text { - } & \text { To spend time lonely } \\
\text { - } & \text { Slow speed due the feeling of inadequacy } \\
\end{array}$ \\
\hline 5 & Somatic & $\begin{array}{ll}\text { - } & \text { Headache } \\
\text { - } & \text { Chest pain } \\
\text { - } & \text { Constipation } \\
\text { - } & \text { Loss of appetite and weight } \\
\end{array}$ \\
\hline
\end{tabular}

On the basis of above description, it is clear that depression is sinkhole of life and it may be developed by different causes. As Yoga Guru Swami Ramdevji Maharaj quoted that "The cause of our joys and sorrows are our good and bad thoughts rather than other person or circumstance. For the ease of the study the causes of depression may be classified into four categories such as:

$>$ Biological causes

$>$ Cognitive causes

$>$ Psychodynamic causes

$>$ Behavioural causes

\section{Biological factors}

The impact of biological factors may be seen in three ways such as genetically, neurochemical and neuroanatomical. Off spring of parents who have depression face three to four times increased rates of depression compared with off spring of healthy parents. The association between parental Mood Depressive Disorder and child diagnosis is moderated by grander parental MDD status. The rates of psychopathology are highest in grand children of parents with a moderately to severely impairing depression. (Weissman, MM. etal.2005).

\section{Cognitive factors:}

The impact of cognitive factors may be seen in two ways. The first one is negative cognitive set and information processing and other one is learned helpless. For example, depressed individual tends to view themselves as helpless, worthless and inadequate. They interpret events in the world in an unrealistically negative and defeatist way, and they see the world as posing obstacles that can't be handled. Finally, they see the future as totally hopeless because their worthlessness will prevent their situation improving.

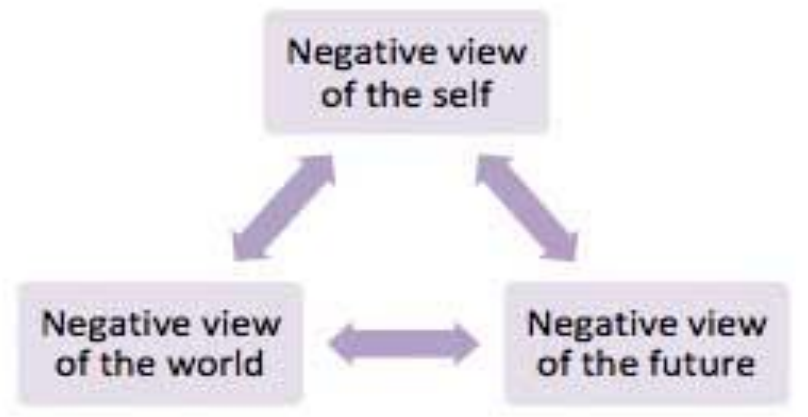

As these three components interact, they interfere with normal cognitive processing, leading to impairments in perception, memory and problem solving with the person becoming obsessed with negative thoughts. cognitive impairment and depression are linked by structural and functional alterations in cortical and subcortical brain areas regulating processing of emotional and cognitive information.

Genetic polymorphisms (BDNF, GSK3B, 5HTT-LPR) and negative life events have been correlated with emotional and cognitive control and some of the above mentioned brain alterations (Gatt et al. 2009, Juhasz et al. 2011, Molendijk et al. 2012). 


\section{Psychodynamic factors}

Depression is also affected by psychodynamic factors. Psychoanalysts historically believed that depression was caused by anger converted into self-hatred ("anger turned inward"), introjection of love object loss, severe super ego demands, excessive narcissistic, oral and anal personality need (Chodoff, 1972), deprivation in the mother child relationship during the first year (Kleine, 1934).

\section{Behavioural factors}

Behavioural factors also plays a very significant role in the development of depression. Behaviourism emphasizes the importance of the environment in shaping behaviour. The focus is on observable behaviour and the conditions through which individuals learn behaviour namely classical conditioning, operant conditioning and social learning theory. Therefore, depression is the result of a person's interaction with their environment. For example, classical conditioning proposes depression is learned through associating certain stimuli. Operant conditioning states that depression is caused by the removal of positive reinforcement from the environment (Lewinsohn, 1974). Social learning theory states behaviour is learned through observation imitation and reinforcement.

\section{Main body (correlation between psychological benefits and yogic practice)}

To reduce depression, yoga plays a very prominent role because yoga is an ancient way of life which was intended to help individuals consciously evolve spiritually. Yoga has been defined as the process of gaining mastery over flections in the mental state. (Yoga Chittavrttinirodhah, chapter 1, verse.2: Patanjali Circa $900 \mathrm{BC}$ ). This sutra suggests that yoga practice helps to reach a state of calm as mentioned in earlier text (the Bhagavad Gita) which states that yoga is synonymous with equilibrium or balance. From this it is apparent that yoga practioners can carry whatever activity they are required to, while certain practices and a particular mental attitude help them to remain calm and in a state of balance.

From the above description it can be stated that a positive correlation is found between psychological benefits and yoga practice in the treatment of physical and mental illness like depression.

By doing yoga psychological well-being and mental health of a person improves. Consisting of activities such as relaxation, meditation, socialization and exercise, yoga has been proven helpful in reducing anxiety and depression.

Proposed mechanism of the yogic techniques duly supported by researchers and great text of Bhagwat $\underline{\text { Gita }}$

Depression can be managed by various yoga practices and by following the psycho- yogic way of life. According to scriptures, bliss is inherent nature of all beings. But in our day to day life, we have lost this inner connection to our own source of joy and bliss. In Sanskrit, the word for health is 'Swasthya' which comes from two root words - 'Swa' which means Self and 'Stha' which means centered. Swasthya essentially means established in one's own Self. According to the spiritual texts, the nature of the Self is Sat-Chit-Ananda or Existence-Consciousness-Bliss. So "Ananda' or bliss is our inherent nature. Yet, we tend to forget this and indulge in depressive thoughts.

The first step towards managing depression is understanding the basic fact that happiness is our true nature. The happiness can be achieved by following ways such as by living in the present, observe our thoughts patterns, alertness of the mind, constant vigil over our negative thoughts, new hope for the future, new project or initiative, prayer and auto- suggestion, like we are strong inside 
and that bliss is our true inner nature. As embodied beings we have a source of inner bliss, which we might have ignored all our life. But, this inner joy can be tapped into by creating an inner connection with our own inner Self. This understanding gives a positive approach to life. It makes us aware of our inner thoughts and conditions. We constantly become aware of our negative thought patterns and will be able to overcome it by asserting our real nature which is full of bliss. This concept is well defined in Bhagwat Geeta. The first chapter of the Bhagavad Gita is called "The Depression of Arjuna". In the battle field of Kurukshetra, Arjuna asks Krishna to drive the chariot to the centre of the battlefield on the eve of a great world war. It is a war involving cousin against cousin and for the first time, Arjuna takes in the reality of the situation, and loses his drive and motivation completely. he doesn't want to 'win' nor would he want to lose the war, so he sits down right there and decides not to fight at all. Arjuna is not only depressed, he is classically anxious. When he says:

\author{
"My limbs sink down \\ My mouth dries up \\ My body trembles \\ And my hair stands on end; \\ The bow falls from my hand \\ My skin burns. \\ I am unable to remain still \\ And my mind seems to ramble"
}

To hear the given statement by Arjun the Lord Krishna preached him the importance of Karma Yoga in life and tries to motivate him by saying that:

\title{
देही नित्यमवध्योउयं देहे सर्वस्य भारत। \\ तस्मात्सर्वाणि भूतानि न त्वं शोचितुमर्हसि || 30||
}

\section{dehī nityam avadhyo 'yam dehe sarvasya bhārata tasmāt sarvāni bhütāni na tvaṁ śhochitum arhasi}

BG.2.30: O Arjun, the soul that dwells within the body is immortal; therefore, you should not mourn for anyone.

The Lord Krishna also preached that:

\section{यं हि न व्यथयन्त्येते पुरुषं पुरुषर्षभ| समदुःखसुखं धीरं सोऽमृतत्वाय कल्पते || $15 \|$}

yam hi na vyathayantyete purușham purușharșhabha sama-duhkha-sukhai் dhïram so 'mritatvāya kalpate

BG.2.15: O Arjun, noblest amongst men, that person who is not affected by happiness and distress, and remains steady in both, becomes eligible for liberation.

On the basis of above description, it can be stated that motivational speech has ultimate power to lift a man up in his life. By listening spiritual and motivational thoughts delivered by great saints, philosophers and also psychologists, a person becomes motivated and confident.

Really, Yoga is one of the best method for elevating one's mood. Through a regular yoga routine, we can pull ourselves out of the pit of depression and rise once more to enjoy vitality and inspiration in our day-to-day live. Yoga is a relaxing form of exercise that can help alleviate depression.

Scientific evidence also indicate that depression can be cured by different yogic techniques. Shahidi et al. tested 70 elderly women (mean age of 65years in the intervention groups and 68 years among 
controls) reporting subjective symptoms of depression with a baseline score of $\geq 10$ on the Geriatric depression scale (GDS) and suggested that 10 session of laughter Yoga or exercise resulted in significant improvement of depressive symptoms from baseline and compared to a waist list control group; however the two active treatment groups did not differ from each other.17,18 ( Vedamurthachar etal., 2006).

In a study of depression in 60 alcohol dependents males (mean age of approximately 35 years) Vedamurthachar et al., demonstrated that subjects undergoing de-addiction treatment had a statistically significant reduction in their scores on the Beck Depression Inventory (BDI), and concurrent reduction in serum cortisol levels when they received Sudarshan Kriya yoga (SKY) compared to their counterparts receiving routine inpatients care 18 (Vedamurthachar et al., 2006). The BDI scores decreased by $75 \%$ at the end of 7 days in the yoga group.

The Sudarshan kriya and related breathing practices have been found to have remarkable therapeutic benefits. These simple, yet powerful, breathing practices have the advantages over many other forms of treatment because they are free from negative side-effects, are much cheaper, and are easy to learn and practice in daily life. These yogic practices are now focus of attention of India's top medical institutes. Sudarshan Kriya is a powerful technique to maintain good health. A person may obtain different physical and psychological benefits by this technique. Some benefits are as follows:

- Eased anxiety and depression

- Reduced cholesterol levels

- Strengthened immune system

- Increased energy

- Improved wellbeing and health

- Providing more harmony, joy and ease in work

- Build community feeling

- Increased awareness of surroundings and self

- Increased patience

- Increased self- esteem and confidence

Steps of Sudarshan Kriya

- To perform Sudarshan Kriya one should first come to Vajrasana.

- Kneel on a yoga mat or rug and make sure that the top part of your feet and your shins are touching the floor. Sit on your heels and relax your body.

- Next, move your buttocks toward the ground, so that you can rest it on the floor. Your ankles should touch the outer part of your hips once you are in position.

- Make sure that you sit up as straight as possible, but keep your body relaxed. If you experience too much pressure on your hips or knees, you can remain seated on your heels, basically, in the Vajrasana position.

- Throughout the entire kriya, you should keep your breathing relaxed. A three-part breath cycle is used in the Sudarshan kriya, which will need a bit of practice to perform properly. In the first cycle, you need to breath in and out in a relaxed manner with the breaths being of equal duration.

- In the second cycle, your exhalations should be twice the duration of the inhalation.

- In the third cycle, your inhalations should be twice the duration of the exhalation. A typical session of a short Sudarshan Kriya should last around 45 minutes and should ideally practised under the supervision of a yoga Instructor at first time. benefits

\section{Conclusion}

On the basis of above description, it can be concluded that psycho-yogic way is a powerful source to keep body calm and cool. A person is able to have sound mental health by doing yoga, to listen motivational speech delivered by saints and to build positive way of thinking. 


\section{$\underline{\text { References }}$}

1. Baron, A, R. (2006). Psychology ( $3^{\text {rd }}$ ed). India: Dorling Kindersley.

2. Chodoff, P. (1972). The depressive personality: a critical review. Archives of general Psychiatry, 27 (5), pp. 666-673.

3. Gatt, J.M., Nemeroff, C.B., Stone, C.D., Paul, R.H., Bryant, R.A., Schofied, P.R., Gordon, E., Kemp, A. H., Williams, L.M. (2009). Interactions between BDNF Val66Met polymorphism and early life stress predict brain and arousal pathways to syndromal depression and anxiety. Molecular Psychiatry, 14, pp.681-695.

4. Juhasz, G., Dunham, J.S., McKie. S., Thomas. E., Downey, D., Chase. D., Lloyd-Williams, K., Toth, Z.G., Platt, H., Mekli, K., Payton, A., Elliott, R., Williams, S.R., Anderson, I.M., Deakin, JF. (2011). The CREB1-BDNF-NTRK2 Pathway in Depression: Multiple Gene-Cognition-Environment Interactions. Biol Psychiatry, 69, pp. 762-771.

5. Kessler, R.C., McGonagle, K.A., Zhao, S., Nelson, C.B., Hughes, M., Eshleman, S., Wittchen, H.U., Kendler, K,S. (1994). Lifetime and 12-month prevalence of DSM-III-R psychiatric disorders in the United States. Arch Gen Psychiatry, 51 (1), pp. 8-9.

6. Klein, M. (1934). Psychogenesis of manic-depressive states: contribution to Psychoanalysis. Hogarth: London.

7. Lewinsohn, P.M. (1974). A behavioural approach to depression. New York: Jhon Wiley \& sons.

8. Molendijk, M, L., Bus, B.A.., Spinhoven, P., Kaimatzoglou, A., Oude Voshaar, R.C., Penninx ,B.W., Van IJzendoorn, M.H,. Elzinga, B.M. (2012). A systematic review and metaanalysis on the association between BDNF val66met and hippocampal volume - A genuine effect or a winners curse? Am J Med Genet B Neuropsychiatr Genet, 159B (6), pp.731-40.

9. Nolen-hoeksema, S. (2001). Gender differences in Depression. Current directions in Psychology Science, 10, pp. 173-176.

10. Shahidi, M., Mojtahed, A., Modabbernia, A., Mojtahed, M., Shafiabady, A., Delavar. (2011). Laughter yoga verses group exercise program in elderly depressed women: a randomized controlled trial. Int. J. Geriatr. Psychiatry, 26, pp. 322-327.

11. Vedamurthachar, A., Janakiramaiah, N., Hegde, J. M., Shetty, T. K., Subbakrishna, D. K., Sureshbabu, S. V. (2006). Antidepressant efficacy and hormonal effects of sudarshana kriya yoga (SKY) in alcohol dependent individual. J. Affect. Disord,,94, pp. 249-253.

12. Virajeshver. (1977). Science of Bhagavvadgita: A study of ancient wisdom through modern science. Delhi: Spiritual India Publishing House,

13. Weissman ,M, M., Wickram, A. P., Nomura, Y, Warner, V., Verdeli, H., Pilowsky, D, J, Grillon, C, Bruder, G. (2005), Families at high and low risk for depression: a 3-generation study. Arch Gen Psychiatry, 62 (1), pp. 29-36. 